\title{
Angiotensin II Type 1-Receptor Antagonist Candesartan Cilexitil Prevents Left Ventricular Dysfunction in Myocardial Infarcted Rats
}

\author{
Akihisa Hanatani $^{1}$, Minoru Yoshiyama ${ }^{1, *}$, Kazuhide Takeuchi $^{1}$, Shokei Kim ${ }^{2}$, Koji Nakayama ${ }^{1}$, Takashi Omura ${ }^{1}$, \\ Hiroshi Iwao ${ }^{2}$ and Junichi Yoshikawa ${ }^{1}$ \\ ${ }^{1}$ First Department of Internal Medicine and ${ }^{2}$ Department of Pharmacology, Osaka City University Medical School, Osaka 545-0051, Japan
}

Received March 24, $1998 \quad$ Accepted June 24, 1998

\begin{abstract}
The purpose of this study was to analyze the effect of the angiotensin II type 1-receptor antagonist candesartan cilexitil on left ventricular systolic and diastolic function and mRNA expression of contractile proteins, collagen, and $\mathrm{Ca}^{2+}$ handling protein in myocardial-infarcted rats. After myocardial infarction, the animals were randomly assigned to candesartan cilexitil-treated or untreated groups (MI). We performed Doppler-echocardiographic examination and measured the hemodynamics at four and twelve weeks after myocardial infarction. Following these measurements, their cardiac mRNA was analyzed. At four weeks in MI, left ventricular end-diastolic dimension increased (Control, $6.2 \pm 0.6 \mathrm{~mm}$; MI, $8.7 \pm 0.6 \mathrm{~mm} ; \mathrm{P}<0.01$ ), fractional shortening decreased (Control, $41 \pm 5 \% ; \mathrm{MI}, 16 \pm 3 \% ; \mathrm{P}<0.01$ ) and $\mathrm{E}$ wave deceleration rate increased (Control, $14.3 \pm 2.0 \mathrm{~m} / \mathrm{sec}^{2} ; \mathrm{MI}, 23.3 \pm 2.3 \mathrm{~m} / \mathrm{sec}^{2} ; \mathrm{P}<0.01$ ). Candesartan cilexitil significantly prevented these changes. The mRNA expressions of $\beta$-myosin heavy chain, $\alpha$-skeletal actin, atrial natriuretic peptide, and collagens I and III in the non-infarcted left ventricle and right ventricle were increased at four weeks and were significantly suppressed by treatment with candesartan cilexitil. At four weeks, $\mathrm{Na}^{+}-\mathrm{Ca}^{2+}$ exchanger mRNA expression was increased, and candesartan cilexitil suppressed this increase. At twelve weeks, sarcoplasmic reticulum $\mathrm{Ca}^{2+}$-ATPase mRNA expression in the infarcted region including the adjacent non-infarcted left ventricle and right ventricle were decreased and candesartan cilexitil restored it to the control level. Candesartan cilexitil prevented the systolic and diastolic dysfunction and abnormal cardiac mRNA expression in myocardial-infarcted rats.
\end{abstract}

Keywords: Ventricular remodeling, Angiotensin II type 1-receptor antagonist, Echocardiography, Gene expression, Diastolic function

Angiotensin-converting enzyme (ACE) inhibitor reduces morbidity and mortality in patients with chronic heart failure and systolic left-ventricular dysfunction as well as in patients who have had a myocardial infarction (1-4). The benefits of ACE inhibitors have been mostly attributed to blockade of angiotensin II production and/or inhibition of kinin destruction. Orally active, non-peptide angiotensin II type 1 (AT1)-receptor antagonists such as losartan or candesartan cilexitil can block this receptor specifically $(5,6)$. Since both ACE inhibitor and AT1-receptor antagonist block the renin-angiotensin system at different levels, both may have a cardioprotective effect. Recently, in the ELITE study, treatment with losartan was associated with unexpected lower mortality than that found with captopril in heart failure patients

* To whom correspondence should be addressed.
(7).

Losartan improved hemodynamics (8) and also prevented left ventricular remodeling after myocardial infarction (9). Our previous study showed that candesartan cilexitil improved hemodynamics and prevented left ventricular dilation (10) and mRNA expressions of fetal contractile proteins and atrial natriuretic peptide (ANP) in the noninfarcted region after myocardial infarction (11). As many as one-third of patients presenting with heart failure are thought to have symptoms attributable to diastolic dysfunction (12). It has become apparent that abnormalities of diastolic filling of the heart play just as great a role, if not a greater role, than systolic function in producing the signs and symptoms of heart failure (13, 14). However, the effect of AT1-receptor antagonist on left ventricular diastolic function after myocardial infarction is not clear. The purpose of this study was to assess 
the effect of candesartan cilexitil on left ventricular systolic and diastolic function after myocardial infarction and cardiac gene expression of contractile protein, collagen and intracellular calcium handling proteins, such as sarcoplasmic reticulum (SR) $\mathrm{Ca}^{2+}$-ATPase and $\mathrm{Na}^{+}-$ $\mathrm{Ca}^{2+}$ exchanger, by Northern blot analysis.

\section{MATERIALS AND METHODS}

Each animal received humane care in compliance with the "Principles of Laboratory Animal Care" of the National Society of Medical Research and the "Guide for the Care and Use of Laboratory Animals" of the National Academy of Sciences.

\section{Experimental protocol}

Male Wistar rats, weighing 290-310 g (Clea Japan, Inc., Osaka), were used in the present experiments. Myocardial infarction was produced in rats by the previously described method of coronary artery ligation $(15,16)$. The same surgical procedures were also performed (Control: four weeks, $n=8$; twelve weeks, $n=8$ ). Myocardialinfarcted rats, which survived $24 \mathrm{hr}$ after surgery, were randomly separated into treated and untreated groups (MI: four weeks, $n=8$; twelve weeks, $n=9$ ). Treated groups of rats were orally administered the AT1-receptor antagonist candesartan cilexitil $(1 \mathrm{mg} / \mathrm{kg})$ in a volume of $2 \mathrm{ml} / \mathrm{kg}$, by gastric gavage once per day for four and twelve weeks after myocardial infarction (candesartan cilexitil: four weeks, $n=9$; twelve weeks, $n=10$ ). The untreated groups were administered vehicle $(5 \%$ gum arabic solution) in the same manner as candesartan cilexitil. There were no significant differences in body weight and blood pressure among the above groups prior to drug treatment.

\section{Doppler-echocardiographic studies}

In this study, we performed transthoracic echocardiography on each rat by modifying the procedure used in the previously described study (17). Rats were lightly anesthetized by an intraperitoneal injection of ketamine hydrochloride ( 25 to $50 \mathrm{mg} / \mathrm{kg}$ ) and xylazine ( 5 to 10 $\mathrm{mg} / \mathrm{kg}$ ) and placed on a specially designed apparatus. Echocardiograms were performed with a commerciallyavailable echocardiographic system equipped with a 7.5-MHz phased-array transducer (SONOS 2500; Hewlett Packard, Andover, MA, USA). M-mode tracings were recorded through the anterior and posterior LV walls at a paper speed of $100 \mathrm{~mm} / \mathrm{sec}$. Moving the transducer toward the cardiac apex and angling anteriorly enabled the acquisition of an apical two-chamber view. The highfrequency neonatal transducers used in this study allowed us to obtain good-quality transthoracic images of the beating rat heart. All measurements were performed by two observers and analyzed by use of the analysis software present on the echocardiography machine.

Pulsed-wave Doppler spectra of mitral inflow were recorded from the apical four-chamber view, with the sample volume placed near the tips of the mitral leaflets and adjusted to the position at which the velocity was maximal and the flow pattern laminar. The sample volume was set at the smallest size available. All Doppler spectra were recorded on paper at $100 \mathrm{~mm} / \mathrm{sec}$ and analyzed off-line as previously described. The numbers represent the mean of at least three consecutive cardiac cycles.

\section{Hemodynamic studies}

One day after the echocardiogram, the rats were anesthetized by intraperitoneal injection of pentobarbital sodium $(35 \mathrm{mg} / \mathrm{kg}$ body weight). Aortic and left ventricular pressures were recorded by inserting a polyethylene tubing catheter into the right carotid artery and advanced into the aorta and then into the left ventricle. Central venous pressure (CVP) was measured by cannulating the right external jugular vein with a PE-50 tubing catheter, which was advanced to the region of the thoracic vena cava. Aortic and central venous pressures were recorded as the mean values determined by electronic averaging, and left ventricular end-diastolic pressure (LVEDP) was obtained by averaging the values for 10 beats. Heart rate was determined from the tracing of aortic pressure.

After these measurements, MI rats and sham-operated rats were decapitated, the chest and abdominal wall were incised, and the heart was quickly removed. The left ventricle, which was separated from the atria and the right ventricle, was opened with an incision along the septum from base to apex. Myocardial infarction size was measured as previously described (16). Rats with less than $20 \%$ of the infarction size were excluded from analysis. After determination of the infarction size, the left ventricle was divided into two regions, the myocardial-infarcted myocardium including two $\mathrm{mm}$ around the infarcted region (adjacent non-infarcted region) and the remote noninfarcted region. Because the infarcted myocardium contains less mRNA and no myocytes, the adjacent noninfarcted region was included in the determination of mRNA expression in infarcted myocardium and designated as "Adjacent". Contractile protein, ANP and calcium handling protein are located in the tissue surrounding the infarct region. However, mRNA expression of collagen in the designated "Adjacent" region represents both the infarct region and the tissue around it. After weighing, the tissues were rapidly frozen in liquid nitrogen and stored at $-80^{\circ} \mathrm{C}$ until use. 


\section{Northern blot hybridization}

The method of RNA extraction and Northern blot hybridization was previously described in detail (18).

The sequence of the oligonucleotide probes used were as follows:

$\alpha$-MHC, $5^{\prime}$-TTGTGGGATAGCAACAGCGA-3'

$\beta$-MHC, $5^{\prime}$-GTCTCAGGGCTTCACAGG-3' $\alpha$-skeletal actin, $5^{\prime}$-GCAACCATAGCACGATGGTC-3' $\alpha$-cardiac actin, 5'-TGCACGTGTGTAAACAAACT-3' 18S, 5'-ACGGTATCTGATCGTCTTCGAACC-3'

The cDNA probes used were rat $\alpha 1$ (I) collagen cDNA (1.3-kb PstI/BamHI fragment) (19), mouse $\alpha 1$ (III) collagen cDNA (1.8-kb EcoRI/EcoRI fragment) (20), rat ANP cDNA (0.825-kb fragment) (21), SR Ca ${ }^{2+}$-ATPase cDNA (2.0-kb fragment) (22) and $\mathrm{Na}^{+}-\mathrm{Ca}^{2+}$ exchanger cDNA (1.2-kb fragment) (23), rat glyceraldehyde-3-phosphate dehydrogenase (GAPDH) (1.3-kb PstI/PstI frag- ment) (24) and rat $18 \mathrm{~S}$ ribosomal RNA. To evaluate mRNA levels, an optical scanner (EPSON GT-8000; Seiko, Tokyo) was utilized for digitizing autoradiograms. The autoradiogram bands in the digitized image were measured for their density with the use of a public domain NIH image program and a computer (Macintosh LC-III; Apple Computer, Inc., USA). For all RNA samples, the density of an individual mRNA band was divided by that of a $18 \mathrm{~S}$ ribosomal RNA band, to correct for differences in RNA loading and/or transfer.

\section{Statistics}

Results were each expressed as a mean \pm S.E. Statistical significance was determined by ANOVA and Duncan's multiple range test. The differences were considered statistically significant at a value of $\mathbf{P}<0.05$.

Table 1. Ventricular weights, hemodynamics and myocardial infarction size in untreated (MI) and AII-receptor antagonist (AII ant)treated rats after myocardial infarction

\begin{tabular}{|c|c|c|c|c|c|c|}
\hline & \multicolumn{3}{|c|}{4 weeks } & \multicolumn{3}{|c|}{12 weeks } \\
\hline & Control & MI & AII ant & Control & MI & All ant \\
\hline n & 8 & 8 & 9 & 8 & 9 & 10 \\
\hline Body weight (g) & $374 \pm 10$ & $380 \pm 9$ & $370 \pm 8$ & $416 \pm 8$ & $408 \pm 10$ & $406 \pm 8$ \\
\hline LV/BW (g/kg) & $1.98 \pm 0.02$ & $2.19 \pm 0.03^{* *}$ & $1.93 \pm 0.03^{\dagger \dagger}$ & $2.04 \pm 0.04$ & $2.32 \pm 0.06^{* *}$ & $2.15 \pm 0.05^{\dagger}$ \\
\hline $\mathrm{RV} / \mathrm{BW}(\mathrm{g} / \mathrm{kg})$ & $0.52 \pm 0.02$ & $0.72 \pm 0.02^{* *}$ & $0.56 \pm 0.01^{\#}$ & $0.54 \pm 0.01$ & $0.89 \pm 0.07^{* *}$ & $0.59 \pm 0.02^{\dagger}$ \\
\hline MAP (mmHg) & $111 \pm 3$ & $106 \pm 2$ & $98 \pm 3^{*}$ & $114 \pm 3$ & $109 \pm 2$ & $96 \pm 4^{*}$ \\
\hline HR (beats/min) & $354 \pm 5$ & $350 \pm 6$ & $352 \pm 8$ & $354 \pm 5$ & $360 \pm 6$ & $366 \pm 10$ \\
\hline LVEDP (mmHg) & $4 \pm 1$ & $21 \pm 3^{* *}$ & $6 \pm 1^{\#}$ & $4 \pm 1$ & $25 \pm 3^{* *}$ & $6 \pm 1^{\dagger}$ \\
\hline CVP (mmHg) & $1 \pm 1$ & $5 \pm 1^{* *}$ & $2 \pm 1^{\dagger t}$ & $2 \pm 0$ & $6 \pm 3^{* *}$ & $2 \pm 1^{\dagger}$ \\
\hline MI size $(\%)$ & - & $38 \pm 3$ & $40 \pm 4$ & - & $40 \pm 4$ & $41 \pm 3$ \\
\hline
\end{tabular}

${ }^{*} \mathrm{P}<0.05,{ }^{* *} \mathrm{P}<0.01$ vs Control; ${ }^{\dagger} \mathrm{P}<0.01$ vs MI. MAP: mean aortic pressure, HR: heart rate, MI size: myocardial infarction size.

Table 2. Doppler echocardiographic measurements in untreated (MI) and AII-receptor anatagonist (AII ant)-treated rats after myocardial infarction

\begin{tabular}{|c|c|c|c|c|c|c|}
\hline & \multicolumn{3}{|c|}{4 weeks } & \multicolumn{3}{|c|}{12 weeks } \\
\hline & Control & MI & AII ant & Control & MI & AII ant \\
\hline $\mathbf{n}$ & 8 & 8 & 9 & 8 & 9 & 10 \\
\hline LVDd (mm) & $6.2 \pm 0.6$ & $8.7 \pm 0.6^{* * *}$ & $7.1 \pm 0.3^{t \dagger}$ & $6.6 \pm 0.3$ & $10.5 \pm 0.6^{* *}$ & $8.0 \pm 0.4^{i \dagger}$ \\
\hline FS $(\%)$ & $41 \pm 5$ & $16 \pm 3^{* *}$ & $31 \pm 4^{\dagger}$ & $38 \pm 6$ & $13 \pm 1^{* *}$ & $24 \pm 2^{* * \dagger}$ \\
\hline PW thickening ( $(\%)$ & $59 \pm 4$ & $29 \pm 7^{*}$ & $41 \pm 10$ & $57 \pm 6$ & $19 \pm 6^{* *}$ & $46 \pm 8^{\dagger}$ \\
\hline E Velocity $(\mathrm{cm} / \mathrm{sec})$ & $66 \pm 2$ & $98 \pm 8^{* *}$ & $81 \pm 5^{\dagger}$ & $66 \pm 8$ & $109 \pm 8^{* *}$ & $87 \pm 4^{* \dagger}$ \\
\hline A Velocity $(\mathrm{cm} / \mathrm{sec})$ & $36 \pm 4$ & $16 \pm 2^{* *}$ & $24 \pm 2^{* * \dagger}$ & $38 \pm 4$ & $13 \pm 2 * *$ & $25 \pm 4^{* \dagger}$ \\
\hline $\mathrm{E} / \mathrm{A}$ & $2.3 \pm 0.5$ & $6.7 \pm 0.9^{* *}$ & $3.5 \pm 0.4^{\dagger t}$ & $2.2 \pm 0.4$ & $8.5 \pm 1.2^{* *}$ & $3.8 \pm 0.6^{t \dagger}$ \\
\hline E Deceleration $\left(\mathrm{m} / \mathrm{sec}^{2}\right)$ & $14.3 \pm 2.0$ & $23.3 \pm 2.3^{* *}$ & $15.3 \pm 1.8^{\dagger}$ & $16.7 \pm 2.5$ & $28.7 \pm 2.9^{* *}$ & $19.5 \pm 1.8^{\dagger}$ \\
\hline
\end{tabular}

${ }^{*} \mathrm{P}<0.05,{ }^{* *} \mathrm{P}<0.01$ vs Control; ${ }^{\dagger} \mathrm{P}<0.05,{ }^{\dagger \dagger} \mathrm{P}<0.01$ vs MI. FS: fractional shortening, $\mathrm{PW}$ : posterior wall. 


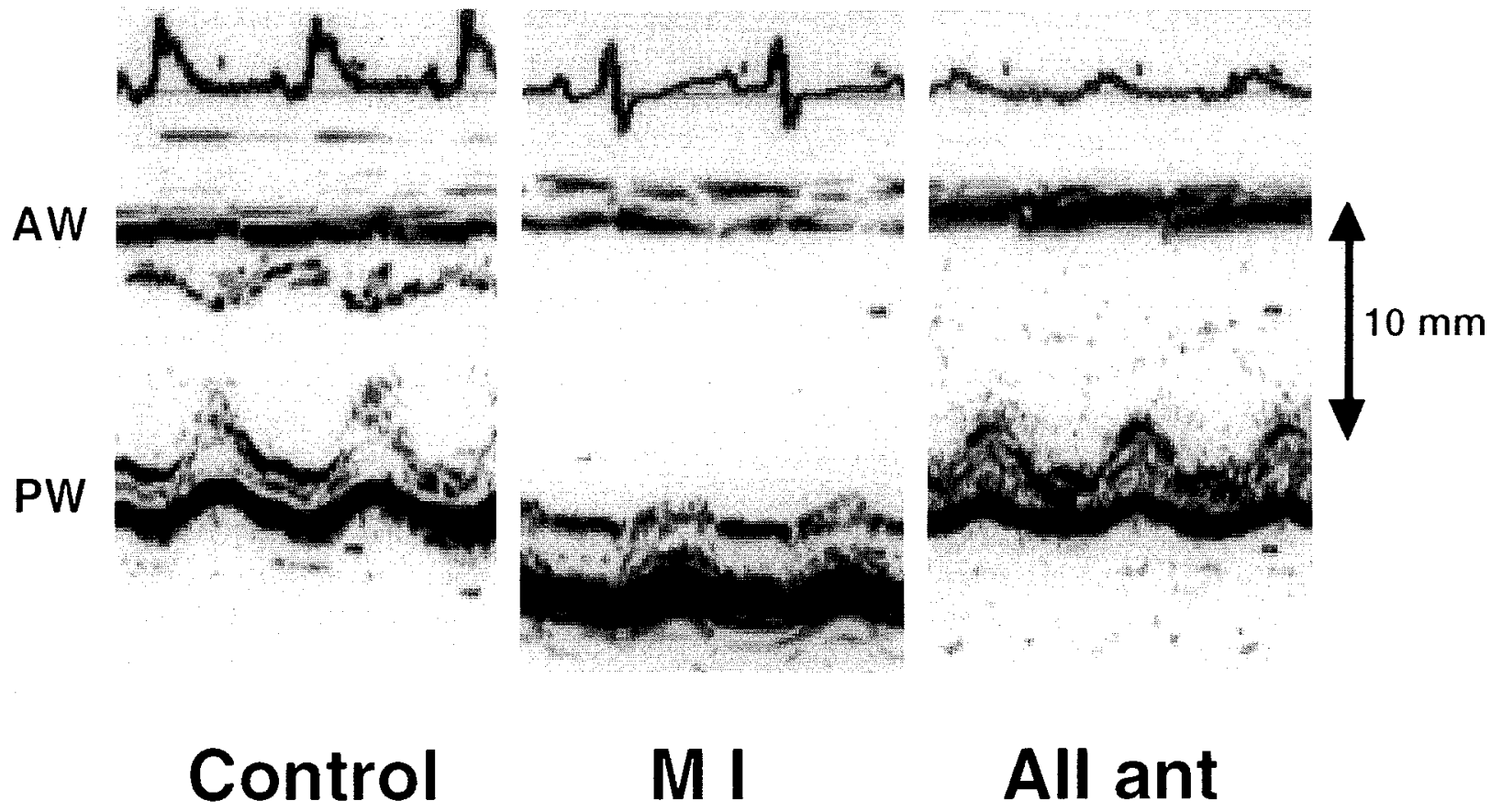

Fig. 1. Examples of M-mode echocardiograms from sham-operated (Control), myocardial-infarcted rats (MI) and myocardial-infarcted rats treated with candesartan cilexitil (AII ant) at twelve weeks. AW indicates the anterior wall and PW indicates the posterior wall. Note the left ventricular cavity dilatation, thinning, and akinesis of the anterior wall and thickening of the posterior wall in MI. Candesartan cilexitil prevented LV dilatation and the decrease of left ventricular PW thickness.

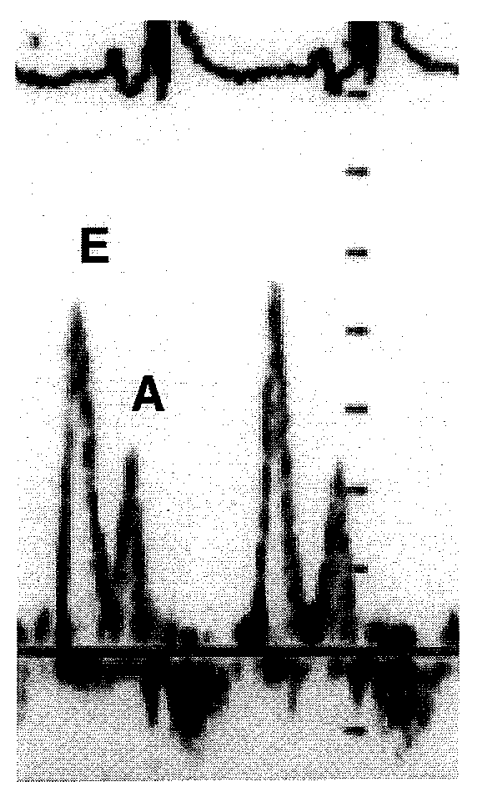

\section{Control}

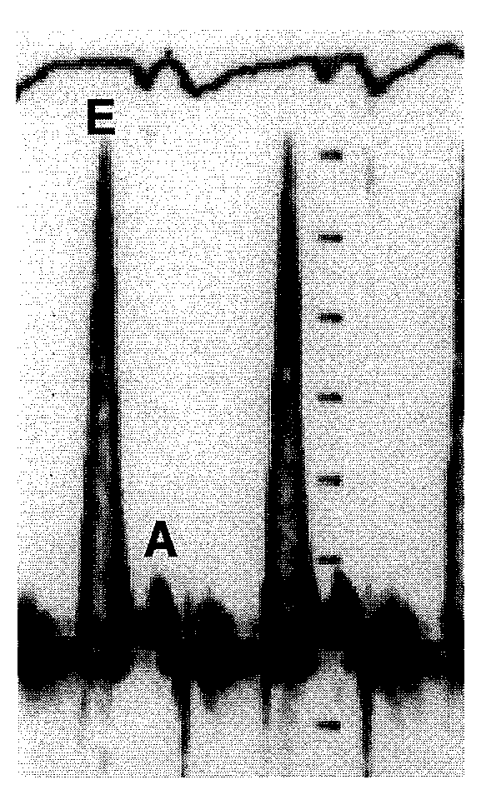

M I

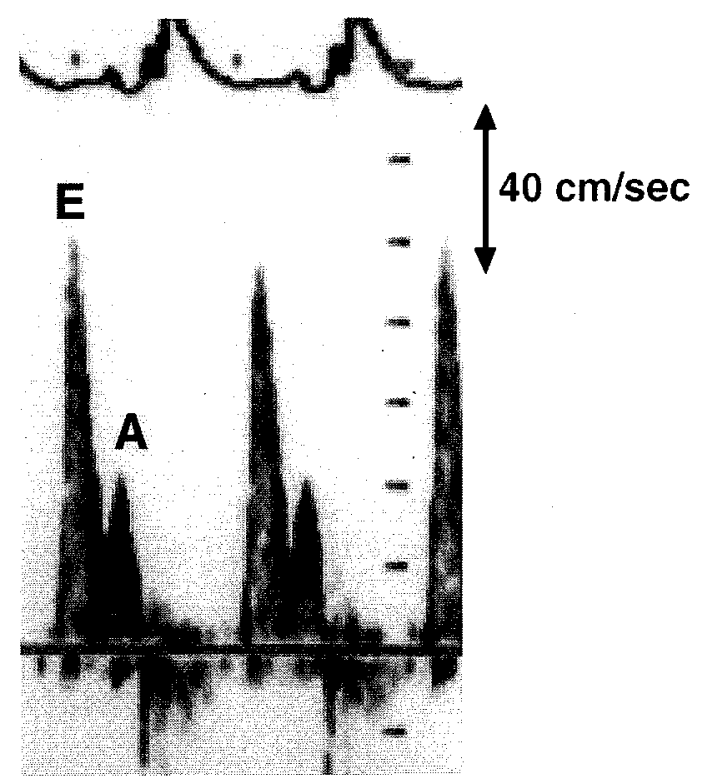

All ant

Fig. 2. Examples of the pulsed wave Doppler spectra of the mitral inflow pattern from sham-operated (Control), myocardial-infarcted rats (MI) and myocardial-infarcted rats treated with candesartan cilexitil (AII ant) at four weeks. Compared with the Control, the mitral inflow pattern from the infarcted rat shows increased peak $E$ wave velocity, rapid deceleration of the $\mathrm{E}$ wave and decreased peak $\mathrm{A}$ wave. The myocardial infarcted rat treated with candesartan cilexitil visually shows a relatively normal transmitral flow pattern. 


\section{RESULTS}

Effect of candesartan cilexitil on ventricular weights and hemodynamics (Table 1)

In myocardial infarcted rats, left and right ventricular weight/body weight ratio increased at four and twelve weeks, and candesartan cilexitil significantly prevented these increases. Mean aortic pressure did not change in myocardial infarcted rats, while candesartan cilexitil significantly decreased it at four and twelve weeks after myocardial infarction. LVEDP and CVP increased in myocardial infarcted rats, and candesartan cilexitil significantly prevented these increases at four and twelve weeks after myocardial infarction.

Echocardiographic assessments of left ventricular geometry and function (Table 2)

Left ventricular cavity size significantly increased in myocardial infarcted rats at four and twelve weeks (LVDd: Control, $6.2 \pm 0.6 \mathrm{~mm}$ versus MI, $8.7 \pm 0.6 \mathrm{~mm}$,
$\mathrm{P}<0.01$, at four weeks; Control, $6.6 \pm 0.3 \mathrm{~mm}$ versus MI, $10.5 \pm 0.6 \mathrm{~mm}, \mathrm{P}<0.01$, at twelve weeks). Candesartan cilexitil significantly prevented the left ventricular cavity dilatation. Myocardial infarcted rats had significant systolic dysfunction, as evidenced by decreased fractional shortening, and candesartan cilexitil improved it at four and twelve weeks. Left ventricular posterior wall thickness decreased at four and twelve weeks. Candesartan cilexitil significantly prevented this decrease at twelve weeks (Fig. 1).

Examples of pulsed-wave Doppler recordings of mitral inflow from three groups at four weeks are shown in Fig. 2. In myocardial infarcted rats, peak early diastolic filling wave ( $\mathrm{E}$ wave) velocity increased and atrial filling wave (A wave) velocity decreased at four weeks, resulting in a marked increase in the ratio of $\mathrm{E}$ wave to $\mathrm{A}$ wave velocity (Control; $2.3 \pm 0.5$ versus MI, 6.7 $\pm 0.9, \mathrm{P}<0.01$ ). Deceleration rate of the $\mathrm{E}$ wave became rapid (Control, $14.3 \pm 2.0 \mathrm{~m} / \mathrm{sec}^{2}$ versus $\mathrm{MI}, 23.3 \pm 2.3 \mathrm{~m} / \mathrm{sec}^{2}, \mathrm{P}<0.01$ ). Candesartan cilexitil significantly prevented the worsen-

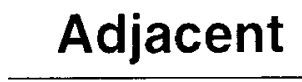

C M I All ant

$\beta-$ MHC

\section{$\alpha$ - Skeletal Actin}
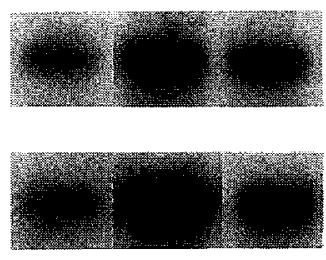

\section{A N P}

\section{Collagen I}

\section{Collagen III}

\section{GAPDH}

\section{$18 S$}
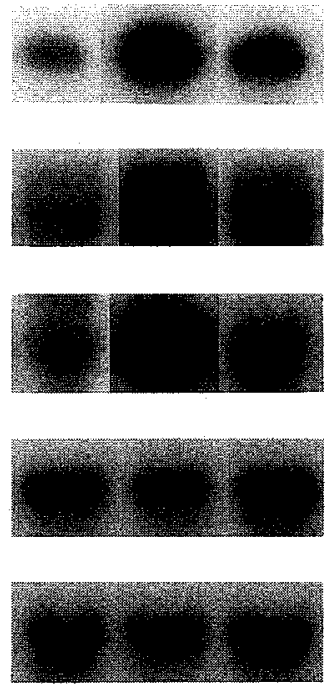
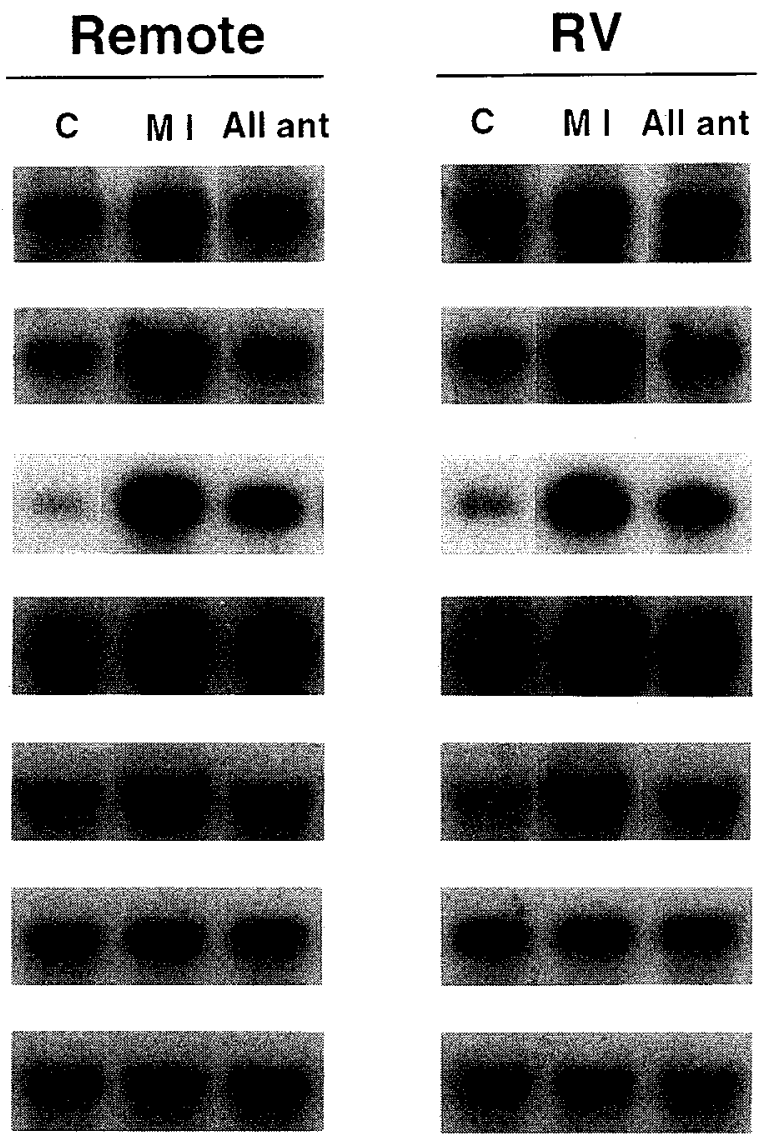

Fig. 3. Typical autoradiograms of Northern blot analysis of the noninfarcted adjacent and remote LV mRNAs for $\beta$-myosin heavy chain ( $\beta$-MHC), $\alpha$-skeletal actin, atrial natriuretic polypeptide (ANP), collagen types I and III, GAPDH and 18S ribosomal RNA at four weeks after myocardial infarction. Adjacent: the infarcted region including the adjacent noninfarcted LV, Remote: the remote noninfarcted LV, RV: right ventricle, C: sham-operated rats, MI: myocardial-infarcted rats treated with vehicle, AII ant: myocardial-infarcted rats treated with candesartan cilexitil. 
ing of diastolic function at four and twelve weeks after myocardial infarction.

$m R N A$ expressions of contractile proteins, ANP, collagens and $\mathrm{Ca}^{2+}$ handling proteins

The results of cardiac gene expressions at four and twelve weeks are shown in Figs. 3 and 4 and Tables 3 and 4. At four weeks, $\beta$-MHC, $\alpha$-skeletal actin and ANP mRNA expressions were increased by 2.6-, 2.4- and 4.7fold $(\mathrm{P}<0.01)$, respectively, in the adjacent region; by 1.4-, 2.8-, 3.9-fold $(\mathrm{P}<0.01)$, respectively, in the remote non-infarcted region; and by $2.2-, 3.4-$ and 6.7 -fold $(\mathrm{P}<0.01)$, respectively, in the RV. Candesartan cilexitil prevented increases of $\beta$-MHC, $\alpha$-skeletal actin and ANP mRNA expression in the three regions. $\alpha$-MHC mRNA expression was decreased by $0.4-$ and 0.5 -fold $(\mathrm{P}<0.01)$, respectively, in the adjacent region and RV. Candesartan cilexitil did not improve these changes. Collagen type I and III mRNA expressions significantly increased, and candesartan cilexitil prevented these increases significantly in all regions. $\mathrm{Na}^{+}-\mathrm{Ca}^{2+}$ exchanger mRNA increased significantly in all regions, while $\mathrm{SR} \mathrm{Ca}^{2+}$-ATPase mRNA did not change. Candesartan cilexitil inhibited the increase of $\mathrm{Na}^{+}-\mathrm{Ca}^{2+}$ exchanger mRNA. GAPDH in the adjacent region decreased significantly (0.8-fold, $\mathrm{P}<0.05$ ).

At twelve weeks, $\alpha$-skeletal actin and ANP mRNAs remained at increased levels, and candesartan cilexitil significantly prevented these increases in all regions. On the other hand, $\beta$-MHC mRNA returned to the control level in all regions. Collagen type I and III mRNAs also increased and candesartan cilexitil significantly prevented these increases in all regions. SR $\mathrm{Ca}^{2+}$-ATPase mRNA decreased to 0.6- $(\mathrm{P}<0.01)$ and 0.6- $(\mathrm{P}<0.05)$ fold, respectively, in the adjacent region and $\mathrm{RV}$, while there was no change in the remote non-infarcted region. Candesartan cilexitil significantly improved these decreases. $\mathrm{Na}^{+}-\mathrm{Ca}^{2+}$ exchanger mRNA returned to the control level in the adjacent region and $\mathrm{RV}$, while it remained increased by 1.8 -fold in the remote non-infarcted region, and candesartan cilexitil prevented this increase.

\section{4 weeks}

\section{SR Ca ${ }^{2+}-$ ATPase}

Adjacent
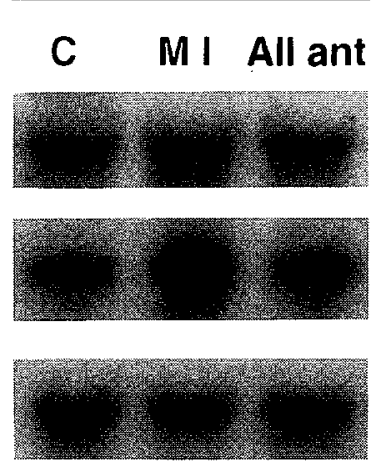

Remote
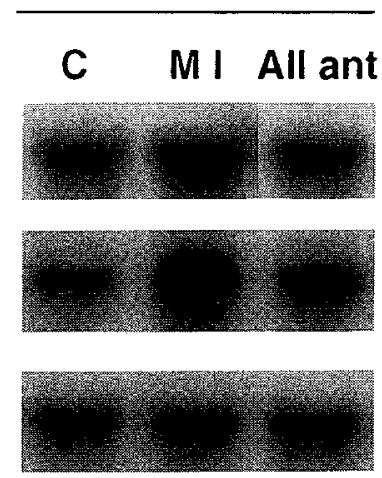

RV

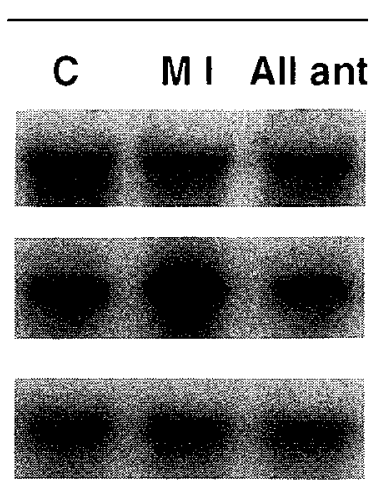

\section{2 weeks}

\section{SR Ca ${ }^{2+}-A T P a s e$}
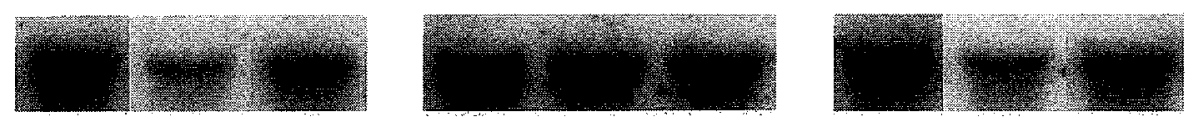

\section{$\mathrm{Na}^{+}-\mathrm{Ca}^{2+}$ exchanger}

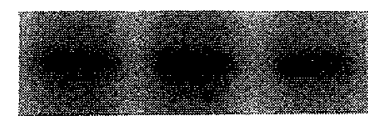

\section{$18 S$}

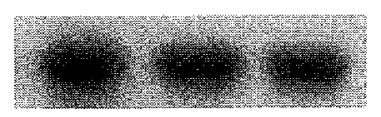

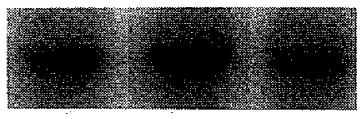
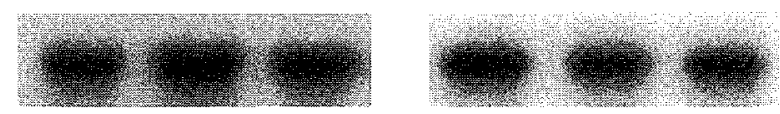

Fig. 4. Typical autoradiograms of Northern blot analysis of the noninfarcted adjacent and remote LV mRNAs for sarcoplasmic reticulum (SR) $\mathrm{Ca}^{2+}$-ATPase, $\mathrm{Na}^{+}-\mathrm{Ca}^{2+}$ exchanger and $18 \mathrm{~S}$ ribosomal RNA at four and twelve weeks after myocardial infarction. Adjacent: the infarcted region including the adjacent noninfarcted LV, Remote: the remote noninfarcted LV, RV: right ventricle, C: sham-operated rats, MI: myocardial-infarcted rats treated with vehicle, AII ant: myocardialinfarcted rats treated with candesartan cilexitil. 
Table 3. mRNA expression in untreated (MI) and AII-receptor antagonist (AII ant)-treated rats at 4 weeks after myocardial infarction (compared with the control)

\begin{tabular}{|c|c|c|c|c|c|c|}
\hline & \multicolumn{2}{|c|}{ Adjacent } & \multicolumn{2}{|c|}{ Remote } & \multicolumn{2}{|c|}{ RV } \\
\hline & MI & AII ant & MI & AII ant & MI & AII ant \\
\hline $\mathbf{n}$ & 8 & 9 & 8 & 9 & 8 & 9 \\
\hline$\alpha$-MHC & $0.4 \pm 0.1 * *$ & $0.4 \pm 0.3^{* *}$ & $0.9 \pm 0.1$ & $0.9 \pm 0.1$ & $0.5 \pm 0.1^{* *}$ & $0.6 \pm 0.2^{* *}$ \\
\hline$\beta$-MHC & $2.6 \pm 0.2^{* *}$ & $2.0 \pm 0.3^{* \dagger}$ & $1.4 \pm 0.1^{* *}$ & $1.0 \pm 0.1^{\dagger+}$ & $2.2 \pm 0.3^{* *}$ & $1.2 \pm 0.1^{\pi}$ \\
\hline$\alpha$-Cardiac actin & $1.0 \pm 0.1$ & $1.0 \pm 0.1$ & $1.1 \pm 0.1$ & $1.0 \pm 0.1$ & $1.1 \pm 0.1$ & $1.0 \pm 0.1$ \\
\hline$\alpha$-Skeletal actin & $2.4 \pm 0.1^{* *}$ & $1.6 \pm 0.1^{* * \pi}$ & $2.8 \pm 0.1^{* *}$ & $1.1 \pm 0.1^{\dagger i}$ & $3.4 \pm 0.2^{* *}$ & $1.3 \pm 0.2^{\dagger \dagger}$ \\
\hline ANP & $4.7 \pm 0.3^{* *}$ & $3.3 \pm 0.3^{* * \dagger \dagger}$ & $3.9 \pm 0.5^{* *}$ & $2.8 \pm 0.2^{* * \dagger}$ & $6.7 \pm 0.6^{* *}$ & $4.0 \pm 1.0^{* * \dagger}$ \\
\hline Collagen I & $12.1 \pm 0.1^{* *}$ & $7.2 \pm 0.5^{* * \dagger}$ & $3.6 \pm 0.3^{* *}$ & $2.4 \pm 0.4^{* * * t}$ & $3.4 \pm 0.3^{* *}$ & $1.4 \pm 0.4^{\pi}$ \\
\hline Collagen III & $8.4 \pm 0.3^{* * *}$ & $5.3 \pm 0.4^{* * \dagger \dagger}$ & $2.2 \pm 0.1^{* *}$ & $1.4 \pm 0.2^{* * \dagger}$ & $3.0 \pm 0.2^{* *}$ & $2.4 \pm 0.2^{* * * \dagger}$ \\
\hline $\mathrm{SR} \mathrm{Ca}^{2+}$-ATPase & $0.9 \pm 0.1$ & $1.0 \pm 0.1$ & $1.0 \pm 0.1$ & $1.0 \pm 0.1$ & $1.1 \pm 0.1$ & $1.1 \pm 0.2$ \\
\hline $\mathrm{Na}^{+}-\mathrm{CA}^{2+}$ exchanger & $1.5 \pm 0.1^{* *}$ & $1.1 \pm 0.2^{\dagger}$ & $1.6 \pm 0.1^{* *}$ & $1.2 \pm 0.1^{\dagger}$ & $1.5 \pm 0.1^{* *}$ & $1.1 \pm 0.1^{\dagger}$ \\
\hline
\end{tabular}

Control $=1.0 \pm 0.0-0.1 .{ }^{*} \mathrm{P}<0.05,{ }^{* *} \mathrm{P}<0.01$ vs Control; ${ }^{\dagger} \mathrm{P}<0.05,{ }^{\dagger} \mathrm{P}<0.01$ vs MI.

Table 4. mRNA expression in untreated (MI) and AII-receptor antagonist (AII ant)-treated rats at 12 weeks after myocardial infarction (compared with the control)

\begin{tabular}{|c|c|c|c|c|c|c|}
\hline & \multicolumn{2}{|c|}{ Adjacent } & \multicolumn{2}{|c|}{ Remote } & \multicolumn{2}{|c|}{$\mathrm{RV}$} \\
\hline & MI & AII ant & MI & AII ant & MI & AII ant \\
\hline $\mathrm{n}$ & 8 & 9 & 8 & 9 & 8 & 9 \\
\hline$\alpha-\mathrm{MHC}$ & $0.7 \pm 0.2$ & $0.6 \pm 0.2$ & $0.9 \pm 0.1$ & $1.0 \pm 0.1$ & $0.5 \pm 0.2^{*}$ & $0.7 \pm 0.1$ \\
\hline$\beta-\mathrm{MHC}$ & $1.2 \pm 0.2$ & $1.0 \pm 0.2$ & $1.0 \pm 0.1$ & $0.9 \pm 0.1$ & $1.3 \pm 0.1$ & $1.1 \pm 0.2$ \\
\hline$\alpha$-Cardiac actin & $1.1 \pm 0.1$ & $1.0 \pm 0.1$ & $1.1 \pm 0.1$ & $1.1 \pm 0.1$ & $1.1 \pm 0.1$ & $1.0 \pm 0.1$ \\
\hline$\alpha$-Skeletal actin & $1.6 \pm 0.2^{* *}$ & $1.2 \pm 0.1^{\dagger}$ & $1.3 \pm 0.1^{*}$ & $0.9 \pm 0.1^{\dagger}$ & $1.4 \pm 0.2^{*}$ & $1.1 \pm 0.1^{\dagger \dagger}$ \\
\hline ANP & $2.7 \pm 0.5^{* *}$ & $1.5 \pm 0.2^{\dagger}$ & $2.2 \pm 0.2^{* *}$ & $1.4 \pm 0.3^{\dagger}$ & $3.0 \pm 0.7^{* *}$ & $1.4 \pm 0.4^{\dagger}$ \\
\hline Collagen I & $2.2 \pm 0.1^{* *}$ & $1.2 \pm 0.1^{\dagger+}$ & $1.4 \pm 0.1^{*}$ & $1.0 \pm 0.1^{\dagger}$ & $1.5 \pm 0.2^{*}$ & $0.8 \pm 0.1^{\dagger}$ \\
\hline Collagen III & $2.5 \pm 0.3^{* *}$ & $1.2 \pm 0.1^{\dagger+}$ & $1.5 \pm 0.2^{*}$ & $1.2 \pm 0.1^{\dagger}$ & $1.9 \pm 0.2^{* *}$ & $1.0 \pm 0.2^{H}$ \\
\hline $\mathrm{SR} \mathrm{Ca}^{2+}$-ATPase & $0.6 \pm 0.1^{* *}$ & $0.9 \pm 0.1^{\dagger}$ & $1.0 \pm 0.1$ & $1.1 \pm 0.1$ & $0.6 \pm 0.2^{*}$ & $0.9 \pm 0.1^{\dagger}$ \\
\hline $\mathrm{Na}^{+}-\mathrm{Ca}^{2+}$ exchanger & $0.9 \pm 0.1$ & $1.0 \pm 0.1$ & $1.8 \pm 0.1^{* *}$ & $1.2 \pm 0.2^{\dagger}$ & $1.3 \pm 0.3$ & $1.1 \pm 0.2$ \\
\hline
\end{tabular}

Control $=1.0 \pm 0.0-0.1 .{ }^{*} \mathrm{P}<0.05,{ }^{* *} \mathrm{P}<0.01$ vs Control; ${ }^{\dagger} \mathrm{P}<0.05,{ }^{\dagger} \mathrm{P}<0.01$ vs MI.

\section{DISCUSSION}

Doppler-echocardiography is currently the primary technique used for evaluating left ventricular diastolic function (25). Increased peak $E$ wave velocity, decreased peak $A$ velocity (or absent $A$ wave), and rapid E-wave deceleration were observed in our rats, and these changes are in accordance with alterations of transmitral flow profiles observed in patients with heart failure with restrictive filling pattern. In experimental and clinical studies, ACE inhibitor treatment is reported to prevent diastolic dysfunction by using Doppler-echocardiography $(26,27)$. Candesartan cilexitil almost completely normalized the restrictive $\mathrm{LV}$ diastolic filling pattern, indicating that candesartan cilexitil might prevent diastolic dysfunc- tion after myocardial infarction.

There are several potential mechanisms whereby candesartan cilexitil might significantly improve diastolic dysfunction. First, we considered the potential effects of alterations in preload. Simply reducing LV filling pressure could explain a large portion of the improvement in the $\mathrm{LV}$ filling pattern. Central blood volume and venous tone are important components of preload. Both of these abnormalities may be corrected by candesartan cilexitil. Second, changes in the passive elastic properties of the myocardium could alter LV filling characteristics in diastole (28). The interstitial fibrosis is believed to increase cardiac stiffness and impair diastolic dysfunction $(29,30)$. In this study, the increased mRNAs of collagen types I and III were inhibited by candesartan cilexitil. The inhi- 
bition of the interstitial collagen accumulation by candesartan cilexitil may prevent diastolic dysfunction after myocardial infarction. Third, a reduction of myocyte hypertrophy during candesartan cilexitil treatment may decrease LV chamber stiffness. In hypertrophic hearts, abnormalities of diastole are common. The prevention of cardiac hypertrophy in non-infarcted myocardium may contribute to improved LV filling characteristics. Fourth, we considered that the prevention of SR dysfunction contributed the prevention of diastolic dysfunction. Myocardial relaxation depends on the function of $\mathrm{SR} \mathrm{Ca}^{2+}$ ATPase, which mediates the reuptake of $\mathrm{Ca}^{2+}$ into the SR following each systole (31). Decreased expression of the SR $\mathrm{Ca}^{2+}$-ATPase gene has been observed experimentally (32) and clinically in failing hearts (33). In this study, we demonstrated that candesartan cilexitil prevented the decease of SR $\mathrm{Ca}^{2+}$-ATPase mRNA expression in adjacent myocardium at twelve weeks, thereby indicating that the decrease of SR $\mathrm{Ca}^{2+}$-ATPase activity may be prevented by candesartan cilexitil.

The $\mathrm{Na}^{+}-\mathrm{Ca}^{2+}$ exchanger is a membrane component that mediates the facilitated bidirectional exchange of $\mathrm{Na}^{+}$for $\mathrm{Ca}^{2+}$ across the sarcolemmal membrane $(34,35)$. Of the $\mathrm{Ca}^{2+}$ flux involved in excitation-contraction coupling, about $80 \%$ occurs across the SR membrane, and $20 \%$ of the $\mathrm{Ca}^{2+}$ flux is moved across the sarcolemma by two transport systems, the $\mathrm{Na}^{+}-\mathrm{Ca}^{2+}$ exchanger and the plasma membrane $\mathrm{Ca}^{2+}$ pumps $(34,35)$. Studer et al. reported that $\mathrm{Na}^{+}-\mathrm{Ca}^{2+}$ exchanger gene expression is enhanced in failing human hearts (36). They speculated that this increase in expression may compensate for depressed SR function via diastolic $\mathrm{Ca}^{2+}$ removal. In our study, $\mathrm{Na}^{+}-\mathrm{Ca}^{2+}$ exchanger gene expression was enhanced in the myocardium without any change in the gene expression of $\mathrm{SR} \mathrm{Ca}^{2+}$ ATPase at four weeks. The present work demonstrates that Studer's opinion is not the general rule in heart failure.

Another interesting aspect of the present work was the finding of a trend toward a decrease in relative wall thickness of the non-infarcted myocardium, and candesartan cilexitil improved global and regional systolic function after myocardial infarction. The decrease in LVPW \% thickness in myocardial infarcted rats implies that the limits of compensation have been reached in the non-ischemic region. This in turn contributes to continuous afterload mismatch and provides an extrinsic mechanism for impairment of systolic function in the non-infarcted region. The decrease in afterload by candesartan cilexitil is reflected in our study by an increased fractional shortening and a decreased mean arterial pressure. Treatment also had an effect on preload, as evidenced in our study by a decrease in left ventricular diastolic diameter and a decreased LVEDP. This indicates a shift of the pressure volume loop down and to the left, back to a more efficient and economic work range. This return to a more economic work will enable the heart to eject more forcefully and decrease the end-systolic volume.

Continued hypertrophy that is inadequate for normalizing increased wall tension activates an initially fetal program of gene expression, exemplified by an increase in $\beta$-MHC and $\alpha$-skeletal actin and accompanied by an increase in the expression of ANP $(11,37,38)$. Myosin and actin isoform shifts improve cardiac muscle efficiency and better correspond to the new velocity of contraction. In addition, ANP is upregulated in the ventricle with increased work load (39), which probably contributes to the increased level of circulating peptide that in turn tends to decrease preload and afterload. Both phenotypic conversions and ventricular production of ANP would normalize the working conditions of the cardiac pump. However, these changes become ineffective during the transition from hypertrophy to failure.

We have previously reported that fetal genes ( $\beta-\mathrm{MHC}$, $\alpha$-skeletal actin, ANP) are predominantly expressed in adjacent non-infarcted myocardium (40). Left ventricular remodeling after myocardial infarction is accompanied by severe hypertrophy and dysfunction of the myocardium adjacent to the infarct (41). A specific and complex response to the mechanical and/or neurohumoral stimuli triggered by the left ventricular remodeling process may exist between the adjacent and remote myocardium. Candesartan cilexitil treatment not only prevented cardiac hypertrophy but also inhibited the gene expression of $\beta$ MHC, $\alpha$-skeletal actin and ANP in both regions. These results support the theory that the AT1 receptor may be involved in the shift to fetal phenotype of myocytes after myocardial infarction as well as after ventricular hypertrophy.

In addition, candesartan cilexitil inhibited the increase of right ventricular weight and fetal and collagen gene expressions. These parameters of the right ventricle appear to be a useful marker of right ventricular remodeling in this model (42), and we showed that candesartan cilexitil prevents the right ventricular remodeling.

In summary, our study demonstrated that candesartan cilexitil prevents systolic and diastolic dysfunction and abnormal mRNA expression of the myocardium in infarcted rats. It follows that an intriguing possibility exists that suitable candesartan cilexitil administration after myocardial infarction may overcome systolic and diastolic dysfunction, thereby altering the natural course towards heart failure. 


\section{REFERENCES}

1 The CONSENSUS Trial Study Group: Effects of enalapril on mortality in severe congestive heart failure. Results of the Cooperative North Scandinavian Enalapril Survival Study (CONSENSUS). N Engl J Med 316, 1429-1435 (1987)

2 ISIS-4 (Fourth International Study of Infarct Survival) Collaborative Group: A randomized factorial trial assessing early oral captopril, oral mononitrate, and intravenous magnesium sulphate in 58,050 patients with suspected acute myocardial infarction. Lancet 345, 669-685 (1995)

3 Pfeffer MA, Braunwald E, Moye LA, Basta L, Brown E Jr, Cuddy TE, Davis BR, Geltman EM, Goldman S and Flaker GC (The SAVE Investigators): Effect of captopril on mortality and morbidity in patients with left ventricular dysfunction after myocardial infarction. Results of the survival and ventricular enlargement trial. N Engl J Med 327, 669-677 (1992)

4 The SOLVD Investigators: Effect of enalapril on survival in patients with reduced left ventricular ejection fractions and congestive heart failure. N Engl J Med 325, 293-302 (1991)

5 Timmermans PB, Wong PC, Chiu AT, Herblin WF, Benfield P, Carini DJ, Lee RJ, Wexler RR, Saye JA and Smith RD: Angiotensin II receptors and angiotensin II receptor antagonists. Pharmacol Rev 45, 205-251 (1993)

6 Inada $Y$, Terashita $Z$, Imura $Y$, Tanabe $M$, Nishikawa $K$ and Kikuchi S: Inhibition of angiotensin converting enzyme by CV3317, a non-sulfhydryl compound. Jpn J Pharmacol 42, 99- 108 (1986)

7 Pitt B, Segal R, Martinez FA, Meurers G, Cowley AJ, Thomas I, Deedwania PC, Ney DE, Snavely DB and Chang PI (Evaluation of Losartan in the Elderly Study, ELITE): Randomised trial of losartan versus captopril in patients over 65 with heart failure Lancet 349, 747-752 (1997)

8 Smits JF, van-Krimpen C, Schoemaker RG, Cleutjens JP and Daemen MJ: Angiotensin II receptor blockade after myocardial infarction in rats: effects on hemodynamics, myocardial DNA synthesis, and interstitial collagen content. J Cardiovasc Pharmacol 20, 772-778 (1992)

9 Schieffer B, Wirger A, Meybrunn M, Seitz S, Holtz J, Riede UN and Drexler $\mathrm{H}$ : Comparative effects of chronic angiotensinconverting enzyme inhibition and angiotensin II type 1 receptor blockade on cardiac remodeling after myocardial infarction in the rat. Circulation 89, 2273-2282 (1994)

10 Yamagishi $H$, Kim S, Nishikimi $T$, Takeuchi $K$ and Takeda $T$ : Contribution of cardiac renin-angiotensin system to ventricular remodelling in myocardial-infarcted rats. I Mol Cell Cardiol 25, $1369-1380$ (1993)

11 Hanatani A, Yoshiyama M, Kim S, Omura T, Toda I, Akioka $\mathrm{K}$, Teragaki $\mathrm{M}$, Takeuchi $\mathrm{K}$, Iwao $\mathrm{H}$ and Takeda $\mathrm{T}$ : Inhibition by angiotensin II type 1 receptor antagonist of cardiac phenotypic modulation after myocardial infarction. J Mol Cell Cardiol 27, 1905-1914 (1995)

12 Liu YH, Yang XP, Sharov VG, Nass O, Sabbah HN, Peterson $E$ and Carretero OA: Effects of angiotensin-converting enzyme inhibitors and angiotensin II type 1 receptor antagonists in rats with heart failure. Role of kinins and angiotensin II type 2 receptors. J Clin Invest 99, 1926-1935 (1997)

13 Giannuzzi P, Imparato A, Temporelli PL, de-Vito F, Silva PL, Scapellato F and Giordano A: Doppler-derived mitral deceleration time of early filling as a strong predictor of pulmonary capillary wedge pressure in postinfarction patients with left ventricular systolic dysfunction. J Am Coll Cardiol 23, $1630-1637$ (1994)

14 Xie GY, Berk MR, Smith MD, Gurley JC and DeMaria AN: Prognostic value of Doppler transmitral flow patterns in patients with congestive heart failure. J Am Coll Cardiol 24, 132- 139 (1994)

15 Fishbein MC, Maclean D and Maroko PR: Experimental myocardial infarction in the rat: qualitative and quantitative changes during pathologic evolution. Am J Pathol 90, 57-70 (1978)

16 Gay RG: Early and late effects of captopril treatment after large myocardial infarction in rats. J Am Coll Cardiol 16, 967-977 (1990)

17 Litwin SE, Katz SE, Morgan JP and Douglas PS: Serial echocardiographic assessment of left ventricular geometry and function after large myocardial infarction in the rat. Circulation 89, 345-354 (1994)

18 Kim S, Ohta K, Hamaguchi A, Omura T, Yukimura T, Miura K, Inada Y, Wada T, Ishimura Y, Chatani F and Iwao H: Role of angiotensin II in renal injury of deoxycorticosterone acetatesalt hypertensive rats. Hypertension 24, 195-204 (1994)

19 Genovese C, Rowe D and Kream B: Construction of DNA sequences complementary to rat alpha 1 and alpha 2 collagen mRNA and their use in studying the regulation of type I collagen synthesis by 1,25-dihydroxyvitamin D. Biochemistry 23, 6210-6216 (1984)

20 Liau G, Yamada Y and de CB: Coordinate regulation of the levels of type III and type I collagen mRNA in most but not all mouse fibroblasts. J Biol Chem 260, 531-536 (1985)

21 Kim S, Ohta K, Hamaguchi A, Yukimura T, Miura K and Iwao $\mathrm{H}$ : Angiotensin II induces cardiac phenotypic modulation and remodeling in vivo in rats. Hypertension 25, 1252-1259 (1995)

22 MacLennan DH, Brandl CJ, Korczak B and Green NM: Amino-acid sequence of a $\mathrm{Ca}^{2+} \mathrm{Mg}^{2+}$-dependent ATPase from rabbit muscle sarcoplasmic reticulum, deduced from its complementary DNA sequence. Nature 316, 696-700 (1985)

23 Low W, Kasir J and Rahamimoff $\mathrm{H}$ : Cloning of the rat heart $\mathrm{Na}^{+}-\mathrm{Ca}^{2+}$ exchanger and its functional expression in $\mathrm{HeLa}$ cells. FEBS Lett 316, 63-67 (1993)

24 Fort P, Marty L, Piechaczyk M, el SS, Dani C, Jeanteur P and Blanchard JM: Various rat adult tissues express only one major mRNA species from the glyceraldehyde-3-phosphate-dehydrogenase multigenic family. Nucleic Acids Res 13, 1431-1442 (1985)

25 Thomas JD and Weyman AE: Echocardiographic Doppler evaluation of left ventricular diastolic function. Physics and physiology. Circulation 84, 977-990 (1991)

26 Litwin SE, Katz SE, Morgan JP and Douglas PS: Long-term captopril treatment improves diastolic filling more than systolic performance in rats with large myocardial infarction. J Am Coll Cardiol 28, 773-781 (1996)

27 Pouleur H, Rousseau MF, van-Eyll C, Stoleru L, Hayashida W, Udelson JA, Dolan N, Kinan D, Gallagher P, Ahn S, Benedict $C R$, Yusuf $S$ and Konstam M (SOLVD Investigators): Effects of long-term enalapril therapy on left ventricular diastolic properties in patients with depressed ejection fraction. Circulation 88, 481 - 491 (1993)

28 Kato S, Spinale FG, Tanaka R, Johnson W, Cooper GIV and Zile MR: Inhibition of collagen cross-linking: effects on fibrillar 
collagen and ventricular diastolic function. Am J Physiol 269, H863-H868 (1995)

29 Weber KT, Janicki JS, Shroff SG, Pick R, Chen RM and Bashey RI: Collagen remodeling of the pressure-overloaded, hypertrophied nonhuman primate myocardium. Circ Res 62, 757-765 (1988)

30 Weber KT, Sun Y, Tyagi SC and Cleutjens JP: Collagen network of the myocardium: function, structural remodeling and regulatory mechanisms. J Mol Cell Cardiol 26, 279-292 (1994)

31 Katz AM: Basic cellular mechanisms of action of the calciumchannel blockers. Am J Cardiol 55, 2B-9B (1985)

32 Bentivegna LA, Ablin LW, Kihara Y and Morgan JP: Altered calcium handling in left ventricular pressure-overload hypertrophy as detected with aequorin in the isolated, perfused ferret heart. Circ Res 69, 1538-1545 (1991)

33 Arai M, Alpert NR, MacLennan DH, Barton P and Periasamy $\mathrm{M}$ : Alterations in sarcoplasmic reticulum gene expression in human heart failure. A possible mechanism for alterations in systolic and diastolic properties of the failing myocardium. Circ Res 72, 463-469 (1993)

34 Bers DM and Bridge JH: Relaxation of rabbit ventricular muscle by $\mathrm{Na}^{+}-\mathrm{Ca}^{2+}$ exchange and sarcoplasmic reticulum calcium pump. Ryanodine and voltage sensitivity. Circ Res 65, 334-342 (1989)

35 Bers DM, Lederer WJ and Berlin JR: Intracellular Ca transients in rat cardiac myocytes: role of $\mathrm{Na}^{+}-\mathrm{Ca}^{2+}$ exchange in excitation-contraction coupling. Am J Physiol 258, C944-C954 (1990)

36 Studer R, Reinecke H, Bilger J, Eschenhagen T, Böhm M, Hasenfuß G, Just H, Holtz J and Drexler H: Gene expression of the cardiac $\mathrm{Na}^{+}-\mathrm{Ca}^{2+}$ exchanger in end-stage human heart failure. Circ Res 75, 443-453 (1994)

37 Schiaffino S, Samuel JL, Sassoon D, Lompre AM, Garner I, Marotte F, Buckingham M, Rappaport L and Schwartz K: Nonsynchronous accumulation of alpha-skeletal actin and beta-myosin heavy chain mRNAs during early stages of pressureoverload-induced cardiac hypertrophy demonstrated by in situ hybridization. Circ Res 64, 937-948 (1989)

38 Chassagne C, Wisnewsky $\mathrm{C}$ and Schwartz K: Antithetical accumulation of myosin heavy chain but not alpha-actin mRNA isoforms during early stages of pressure-overload-induced rat cardiac hypertrophy. Circ Res 72, 857-864 (1993)

39 Izumo S, Nadal GB and Mahdavi V: Protooncogene induction and reprogramming of cardiac gene expression produced by pressure overload. Proc Natl Acad Sci USA 85, 339-343 (1988)

40 Yoshiyama M, Takeuchi K, Hanatani A, Kim S, Omura T, Toda I, Teragaki $M$, Akioka $\mathrm{K}$, Iwao $\mathrm{H}$ and Yoshikawa $\mathrm{J}$ : Differences in expression of sarcoplasmic reticulum $\mathrm{Ca}^{2+}$. ATPase and $\mathrm{Na}^{+}-\mathrm{Ca}^{2+}$ exchanger genes between adjacent and remote noninfarcted myocardium after myocardial infarction. J Mol Cell Cardiol 29, 255-264 (1997)

41 Kramer CM, Lima JA, Reichek N, Ferrari VA, Llaneras MR, Palmon LC, Yeh IT, Tallant B and Axel L: Regional differences in function within noninfarcted myocardium during left ventricular remodeling. Circulation 88, 1279-1288 (1993)

42 Yoshiyama M, Takeuchi K, Hanatani A, Shimada T, Takemoto Y, Shimizu N, Omura T, Kim S, Iwao $\mathrm{H}$ and Yoshikawa J: The effect of cilazapril on ventricular remodeling assessed by Doppler-echocardiographic assessment and cardiac gene expression. Cardiovasc Drug and Ther 12, 57-70 (1998) 